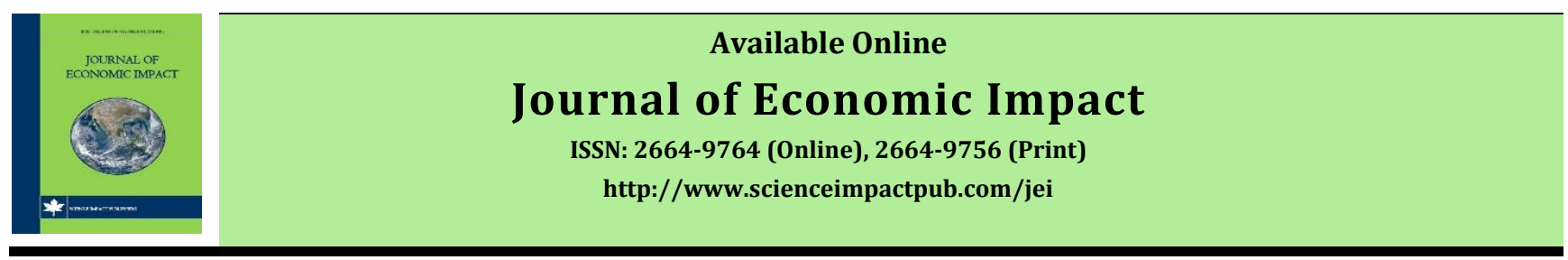

\title{
FACTORS AFFECTING THE INCOME OF RURAL WOMEN: AN EVIDENCE FROM DISTRICT FAISALABAD, PAKISTAN
}

\author{
Rubina Akhtar a, Muhammad Amjed Iqbal a,*, Allah Bakhsh ${ }^{\text {b }}$ \\ a Institute of Agricultural and Resource Economics, University of Agriculture, Faisalabad, Pakistan \\ ${ }^{b}$ Institute of Agricultural Extension and Rural Development, University of Agriculture, Faisalabad, Pakistan
}

\section{ARTICLE INFO}

\section{Article history}

Received: February 16, 2020

Accepted: December 25, 2020

Published: December 29, 2020

\section{Keywords}

Women participation

Labor force

Income

Factors

Faisalabad

\section{ABSTRACT}

The fundamental point of the investigation was to assess the effect of various components on the pay of rural women in the region Faisalabad. For this, a stratified sampling procedure was utilized. At the first stage, the Faisalabad district was chosen purposively. In the second stage, five regions of each class were chosen through a simple random sampling technique. The total sample size was comprised of 150 respondents. A pre-tested questionnaire was used to gather the information from chosen respondents through the personal interview technique. Descriptive Statistics were used to explore the socio-economic characteristics of rural women. Multiple linear regression analysis was used to estimate the impact of different factors affecting the income of rural women. According to the estimated results, the age of the respondents has a positive and highly significant impact. This indicates that one year increase in the age of women would increase her income by 0.314 units. The estimated result of education described that for every one year in an increase in schooling year of women will increase the income by 0.191 unit. The variable of family sizes of the respondents has a significant and positive effect on the respondent's income. Working hours of the respondents have a positive and significant effect on respondent's income. The satisfaction of the respondents has a positive and significant effect on the respondent's income. Female participation in the market increases with the growing levels of higher education. It is recommended that the government should provide education to the females especially in rural areas.

* Corresponding Author: Muhammad Amjed Iqbal

Email: amjadiqbal1775@yahoo.com

(C) The Author(s) 2020.

\section{INTRODUCTION}

Women have been normally considered as the more fragile and weak part of Pakistani society regarding education, health, employment, and business opportunities. However, during the recent few decades, a lot of attention has been drawn towards the issues of women all over the world (Park, 2011). According to the Gender Development Index (GDI), West Pakistan has been rated the poorest (0.179) among the South Asian countries where the common index is 0.2 (UNDP, 2000). As per the Household Integrated Income and Consumption Survey (HIICS) 2015-2016 National/Provincial levels, the literacy rate of the populace stayed $70 \%$ male and 48\% female in Pakistan. The literacy rate was higher in urban areas showing $81 \%$ male and $68 \%$ female while in rural areas it was $63 \%$ male and $36 \%$ female as shown in figure 1. Educating women may be a core factor of collective economic results later in life, adult coaching and skills development programs are vital to women's economic liberation. A recent review of women and girls' economic empowerments programmed valuations found that joint interventions that mix vocational education with life skills can be valuable; such programs are often extremely efficient and might be offered effectively in a very wide selection of contexts with changes to suit native context (Taylor and Pereznieto, 2014). 
The barriers to women's education, whether or not general or quickly caused by shocks, have serious effects for his or her visions later in life. The opportunity cost of education of females is high in low-income countries (Peet et al., 2015). A further year of school for ladies will later increase wages by around $10 \%$, rising to $15-25 \%$ for every additional year of lyceum, and nearly $17 \%$ for tertiary education (Herz and Sperling, 2004). In rural economy agriculture is a major economic source all over the planet. Agriculture has a major contribution to every country's development. Developing nations are more reliant on the agricultural-based economy. Several Asian and South American countries turn out the key food for everywhere on the planet. China and America feature a heap of agricultural resources. It's the requirement of the time to boost the assembly whereas victimization the new technology in agriculture. The countries that are victimization the new trends and ways are increasing very fast during this field (Kwa, 2001).

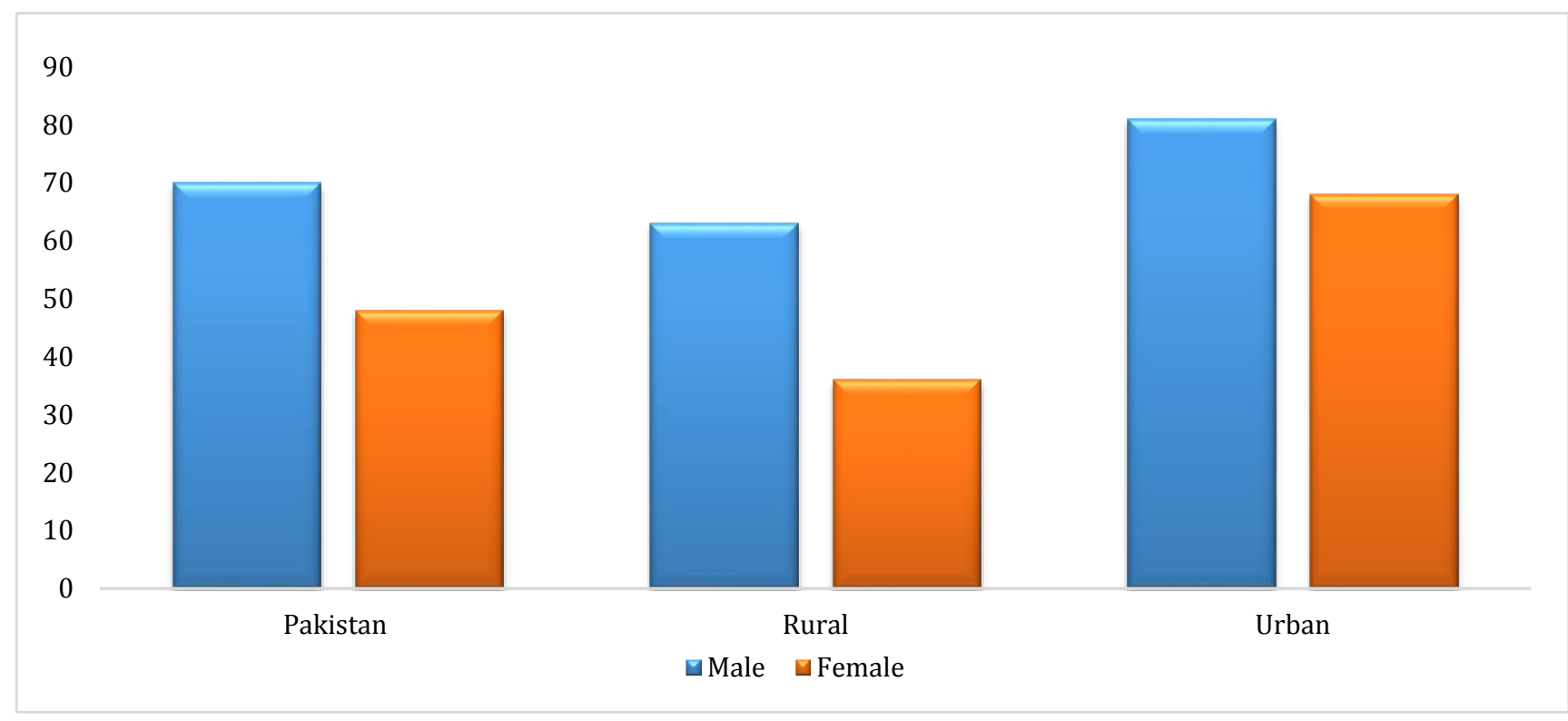

Figure 1. Literacy rate of Pakistan.

Source: PSLM Section, Pakistan Bureau of Statistics.

It is the reality that millennium developmental goals cannot be achieved without uplifting rural women of the world. The role of rural women in economic contribution is a very important part of each community in the modern world. Women have fewer abilities as compared to men in developmental and economic opportunities even with a lot of family burden (Lanjouw and Lanjouw, 2001). The additional employment is unpaid and ambit the capability of girls to participate and interact in economic activities. However, the character of tasks needed ladies to remain close to the house that limits their choice to work for wage-earning. What is more, insufficiency of your time makes many females started bungalow industries like handcraft and artistic art that are usually characterized by low returns. While norms dissent in terms of culture and religion; as a result, it's calculable that rural ladies spent $85-90 \%$ of their time in the family food process and preparation (Fontana and Natali, 2008).

Adebowale (2014) observed the economic contribution of rural females created by the community development through handcraft. Like alternative ancient artistic, it's survived competitions rising from the modernization of the assembly method and transmission of substitutes like plastics, and the metal product. Any significant pottery studies should take cognizance of the natural surroundings, still because the society that turns out and uses the pottery wares, it's a standard method of creating pots by the utilization of hand and a mother to female offspring line talent transfer.

Educated women contribute economically to their families. Education typically results in financial gain and productivity, for people and for nations as well. Several analysis pieces of evidence show that educating women typically produces bigger gains in productivity and financial gain than educating boys, and educating women has the maximum amount or additional impact on the national economic process. Within the more and more open world economy, countries with high rates of illiteracy and gender gaps in instructional attainment tend to be less competitive, as a result, foreign investors get cheap labour (Aslam et al., 2013). A growing body of analysis suggests that education helps empower ladies to face up for themselves and their youngsters. It will bring 
advantages not solely to ladies and their youngsters, however to the broader community and society through simpler and representative governance. Studies in several countries make sure that each maternal and paternal education has an effect on children's instructional attainments (Herz and Sperling, 2004).

\section{METHODOLOGY}

\section{Sampling}

For the analysis purpose data was collected from 150 women of the rural areas of Faisalabad. A sample is also outlined as "a portion of all the weather during a population that's accustomed acquires info concerning the complete population". The massive cluster of individuals is known as a sample (Nachmias and Nachimas, 1992). It's impractical for a man of science to check the complete population state of affairs and event of the universe because of the short amount of your time and a huge population of the universe, therefore a sample is drawn. Five villages were selected randomly and 30 respondents were selected from each village.

\section{Data Collection}

It is quite essential that in the development of activity instruments, all aspects of information quality and attributes ought to be taken into consideration. Both qualitative and quantitative ways were accustomed to getting important and careful data. Data were collected employing a form consisting of each open and closed complete query relevant to the objectives of the study. Pretesting of the data collection instrument is necessary to find out the weaknesses and strengths of the survey.

\section{Data Analysis}

The collected data were coded and arranged in a proper format. The income was regressed with different variables to check the impact of those variables on the income of the women. The equation showing the relation of the dependent variable with other independent variables is given below. $\mathrm{Y}=\mathrm{f}(\mathrm{Xi})$

Where $\mathrm{Y}=$ Income of the women
$\mathrm{Xi}=$ Independent variables

To analyse the women's role in the rural economy in the rural economy, applied the multiple regression model. In the present research, the author had used the following model.

$Y=\beta o+\beta_{1} X_{1}+\beta_{2} X_{2}+\beta_{3} X_{3}+\beta_{4} X_{4}+\beta_{5} X_{5}+\beta_{6} X_{6}+\mu$

$Y=$ Income of the respondent (Thousands)

$\beta_{\mathrm{o}}=$ Intercept term of the model

$\beta_{1}, \beta_{2}, \beta_{3}, \beta_{4}, \beta_{5}$ and $\beta_{6}$ are the parameters in model to be estimated.

$\mathrm{X}_{1}, \mathrm{X}_{2}, \mathrm{X}_{3}, \mathrm{X}_{4}, \mathrm{X}_{5}$, and $\mathrm{X}_{6}$ are the independent variables of the model to be estimated.

$\mathrm{X}_{1}=$ Age (Years)

$\mathrm{X}_{2}=$ Qualification

$\mathrm{X}_{3}=$ Family size

$\mathrm{X}_{4}=$ Working hours (Per day)

$\mathrm{X}_{5}=$ Motivation ( 1 if Yes, otherwise 0 )

$\mathrm{X}_{6}=$ Satisfaction ( 1 if Yes, otherwise 0 )

$\mathrm{X}_{5}$ and $\mathrm{X}_{6}$ are the dummy variables

$\mu=$ Stochastic error term.

\section{RESULTS AND DISCUSSION}

\section{Socio-economic Characteristics of Rural Women}

Age may be an important demographic variable which is a very important variable for the estimation of income. Age tells the maturity level of an individual because aged persons have additional expertise as compared to less aged persons. According to the distribution of frequency of respondents as shown in Table 1 they were only 4 respondents below the age of 21 years. It is clearly shown that only $2.7 \%$ of women have an age of less than 21 years. Females in the age class of 21- 40 years were 102 and their proportion was $68.0 \%$. There were 44 women within the age group of 41-60 constituting 29.3 percent of the total sample size. Similar people were found by the government of Islamic Republic of Pakistan (2015), regarding $17 \%$ population of Islamic Republic of Pakistan belonged to people (20-24) and $37 \%$ population belong to people (25-34) and $47 \%$ population of Pakistan had thirty-five and on top of age.

Table 1. Socio-economic characteristics of rural women.

\begin{tabular}{llll}
\hline Variable & Value & Frequency & Percent \\
\hline Age & $1-20$ & 4 & 2.7 \\
& $21-40$ & 102 & 68.0 \\
& $41-60$ & 44 & 29.3 \\
\hline Education & Primary & 30 & 20.0 \\
& Middle & 22 & 14.7 \\
& Matric & 17 & 11.3 \\
\hline
\end{tabular}




\begin{tabular}{llll}
\hline & Secondary & 17 & 11.3 \\
& Graduation and above & 64 & 42.7 \\
\hline Total family members & $1-5$ & 54 & 36.0 \\
& $6-10$ & 68 & 45.3 \\
& $11-15$ & 18 & 12.0 \\
& $16-20$ & 8 & 5.3 \\
\hline Working hours & $21-25$ & 2 & 1.3 \\
\hline Total income & $1-5$ & 20 & 13.3 \\
& $6-10$ & 88 & 58.7 \\
& $11-15$ & 42 & 28.0 \\
\hline & $1000-20000$ & 97 & 64.7 \\
\hline
\end{tabular}

Only 42.7 percent of women were having the qualification of graduation or more than graduation while 11.3 percent of women have matric degree. Women who have completed primary education were 20 percent. The data shows that 28 percent of women have been working for 11 to 15 hours daily while 58.7 percent of women have been working 6 to 10 hours per day. The majority of the women (64.7\%) were earning 1000 to 20000 thousand rupees monthly. Only 7.3 percent of women were earning 40001 to 60000 rupees per month.

\section{Factors Affecting the Income of Rural Women}

The estimation of R2 is 0.536 as shown in Table 2 which demonstrates that the 53 percent variety in pay was clarified by independent variables. The estimated value of the F-test is 23.473 which shows the overall fitness of the model.

Regression may be an applied mathematics method that features techniques and strategies to research and to draw helpful results on the premise of the information. Regression may be a helpful technique to envision the connection between variables. It shows the modification in the typical price of the variable quantity once the variable quantity changes. It tells concerning the common price of variable quantity once the variable quantity is fastened. Here seven informative variables are regressed against one response variable. The regression results presented that six variables are a significant relationship with income while one variable is insignificant on $5 \%$ and $10 \%$ and only one variable is non-significance.

Table 2. Factors affecting the income of rural women.

\begin{tabular}{|c|c|c|c|c|}
\hline Variable & B & Std. Error & $\mathrm{t}$ & Sig. \\
\hline (constant) & 0.228 & 0.392 & 5.681 & $0.000^{* * *}$ \\
\hline Age & 0.314 & 0.157 & 8.367 & $0.000^{* * *}$ \\
\hline Qualification & 0.191 & 0.084 & 2.266 & $0.025^{*}$ \\
\hline Family size & 0.211 & 0.079 & 2.672 & $0.008^{* *}$ \\
\hline Working hours & 0.306 & 0.122 & 2.512 & $0.013^{*}$ \\
\hline Satisfaction & 0.127 & 0.071 & 1.778 & $0.078^{*}$ \\
\hline Motivation & 0.119 & 0.147 & 0.811 & 0.419 \\
\hline F test & 23.47 & & & \\
\hline
\end{tabular}




R Sqaure 0.536

Adjusted R Square $\quad 0.514$

Note: ${ }^{* * *},{ }^{* *}, *$ significant at 1, 5 and 10 percent level of significance respectively.

The coefficient of the age of the respondents has high significance at a $1 \%$ level of confidence interval. The value shows a positive association with income. This indicates that a one-unit increase in age would increase the income by 0.314 units on average. The coefficient education described that for every one-unit increase in education led to an increase of 0.191 units in income. Female participation in the market increases with the growing levels of higher education. It is recommended that the government should provide education to the females especially in rural areas. In regression results, the family sizes of the respondents have a significant effect on the respondent's income. The family size of the respondents showed a positive relationship with income. This result shows that 0.211 units on the average family size would increase one unit of income. It is the actuality that more people work can earn more income.

The working hours of the respondents have a significant effect on the respondent's income. The family size of the respondents showed a positive relationship with income. This result shows that 0.306 units on average working hours would increase one unit of income. The satisfaction of the respondents has a positive and significant effect on the respondent's income. This result showed that 0.127 units on the average of satisfaction would increase one unit of income. The motivation of the respondents has an insignificance effect on the respondent's income. The motivation of respondents showed a positive relationship with income. This result shows that 0.119 units on the average of motivation would increase one unit of income.

\section{CONCLUSIONS AND RECOMMENDATIONS}

According to the estimated results, the age of the respondents has a positive impact which is highly significant. Female participation in the market increases with the growing levels of higher education. It is recommended that the government should provide education to females especially in rural areas. The variable of family sizes of the respondents has a significant and positive effect on the respondent's income. The family size of the respondents showed a positive relationship with income. It is the actuality that more people work can earn more income. Working hours of the respondents have a positive and significant effect on respondent's income. The family size of the respondents showed a positive relationship with income. The satisfaction of the respondents has a positive and significant effect on the respondent's income. Education had a positive impact on the social-economic status of the family. But for getting an education females to face many problems like gender inequalities. parents were not sending their daughters to schools because of distance problems, community constraints, family restrictions, transportation problems, due to increase in family size, security issues, and because of low income, parents were not sending their daughters to schools. To improve the women's literacy rates and level of female education ratio, a separate education policy for women must be developed. The flexible technique should be provided to working women because they show aggressive behaviour due to the burden of work.

\section{REFERENCES}

Adebowale, B.A., 2014. Women involvement in handmade pottery and marketing concept strategy. Journal of Economics and Sustainable Development, 5(6), 150-159.

Aslam, M., Rasool, S., Mehmood, I., 2013. Socio-cultural determinants of women education: a case study from district Faisalabad, Punjab, Pakistan. The Women-Annual Research Journal of Gender Studies, 5, 75-88.

Fontana, M., Natali, L., 2008. Gendered patterns of time use in Tanzania: Public investment in infrastructure can help. Paper prepared for the IFPRI Project on-Evaluating the long-term impact of gender focused policy interventions. Mimeo. Available at www.ids.ac.uk.

Herz, B., Sperling, G.B., 2004. What works in girls" education, evidences and policies from the developing world? Council on Foreign Relations, Inc. USA.

Kwa, A., 2001. Agriculture in developing countries: which way forward? Trade-related agenda, Development and Equity (T.R.A.D.E.) Occasional Papers 4. Retrieved

from https://focusweb.org/publications/2001/agr iculture_which_way_forward.html.

Lanjouw, J.O., Lanjouw, P., 2001. The rural non-farm sector: issues and evidence from developing countries. Agricultural Economics, 26(1), 1-23. 
Park, S., 2011. Returning to school for higher returns. Economics of Education Review, 30(6), 1215-1228.

Peet, E.D., Fink, G., Fawzi, W., 2015. Returns to education in developing countries: Evidence from the living standards and measurement study surveys. Economics of Education Review, 49, 69-90.

Taylor, G., Pereznieto, P., 2014. Review of evaluation approaches and methods used by interventions on women and girls' economic empowerment. Overseas Development Institute, pp.1-62.

UNDP, 2000. Human development report 2000: Human rights and human development. Retrieved from http://hdr.undp.org/sites/default/files/r eports/261/hdr_2000_en.pdf.

Publisher's note: Science Impact Publishers remain neutral with regard to jurisdictional claims in published maps and institutional affiliations.

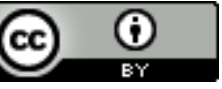

Open Access This article is licensed under a Creative Commons Attribution 4.0 International License, which permits use, sharing, adaptation, distribution and reproduction in any medium or format, as long as you give appropriate credit to the original author(s) and the source, provide a link to the Creative Commons license and indicate if changes were made. The images or other third-party material in this article are included in the article's Creative Commons license, unless indicated otherwise in a credit line to the material. If material is not included in the article's Creative Commons license and your intended use is not permitted by statutory regulation or exceeds the permitted use, you will need to obtain permission directly from the copyright holder. To view a copy of this license, visit https://creativecommons.org/licenses/by/4.0/.

(C) The Author(s) 2020 